\title{
Comparison of the Antagonistic Potential of the Entomopathogenic Bacterium Serratia nematodiphila GCSR38 with other Effective Microorganisms for the Control of Rice Bacterial Leaf Blight
}

\author{
Waraporn Sutthisa (i) \\ Department of Biology, Faculty of Science, Mahasarakham University, Kantarawichai District, \\ Maha Sarakham Province - 44150, Thailand.
}

\begin{abstract}
The efficacy of antagonistic microorganisms and secondary metabolites of entomopathogenic bacteria was evaluated in vitro and in vivo against Xanthomonas oryzae pv. oryzae (Xoo), a causal agent of rice bacterial leaf blight. The effect of the culture filtrates of the microorganisms was tested against Xoo, using the agar well diffusion assay. Trichoderma sp. UB05/3 was the most effective against Xoo. However, the results were not statistically different from those of the entomopathogenic bacterium Serratia nematodiphila GCSR38 with a $22.97 \mathrm{~mm}$ and $19.15 \mathrm{~mm}$ zone of inhibition, respectively. The effect of the secondary metabolite crude extracts of antagonistic microorganisms $(2,000 \mu \mathrm{g} / \mathrm{ml})$ on Xoo inhibition was tested by the paper disc diffusion method. Only S. nematodiphila GCSR38 was able to control Xoo, with an inhibition zone of $17.60 \mathrm{~mm}$. Minimum inhibitory concentration (MIC) was determined using a 96-well microtiter plate. The MIC of secondary metabolites crude extracts of $S$. nematodiphila GCSR38 was $1,000 \mu \mathrm{g} / \mathrm{ml}$ and the minimum bactericidal concentration (MBC) was 1,000 $\mu \mathrm{g} / \mathrm{ml}$. The efficacy of the secondary metabolite crude extract of $S$. nematodiphila GCSR38 against Xoo was tested using the detached leaf technique; the secondary metabolite crude extracts controlled the disease, with $\mathbf{2 4 . 4 5 \%}$ and $\mathbf{1 5 . 5 6 \%}$ disease severity when used before and after inoculation with Xoo, respectively. Inoculation with $X o 0$ alone resulted in a disease severity of $44.45 \%$. The secondary metabolite crude extracts of $S$. nematodiphila GCSR38 can reduce disease severity of bacterial leaf blight in rice by $\mathbf{2 8 . 8 9 \%}$, whereas zinc thiazole causes a disease severity of $\mathbf{2 2 . 2 2 \%}$ and Xoo alone causes a disease severity of $66.67 \%$.
\end{abstract}

Keywords: Entomopathogenic bacteria, Minimum Inhibitory Concentration (MIC), secondary metabolite

*Correspondence: waraporn.s@msu.ac.th

(Received: November 25, 2021; accepted: January 22, 2022)

Citation: Sutthisa W. Comparison of the Antagonistic Potential of the Entomopathogenic Bacterium Serratia nematodiphila GCSR38 with other Effective Microorganisms for the Control of Rice Bacterial Leaf Blight. J Pure Appl Microbiol. 2022;16(1):557566. doi: 10.22207/JPAM.16.1.54

(C) The Author(s) 2022. Open Access. This article is distributed under the terms of the Creative Commons Attribution 4.0 International License which permits unrestricted use, sharing, distribution, and reproduction in any medium, provided you give appropriate credit to the original author(s) and the source, provide a link to the Creative Commons license, and indicate if changes were made. 


\section{INTRODUCTION}

Rice (Oryza sativa L.) is a major economic crop in Thailand, and it is the staple food for more than half of the world's population. In many places worldwide, including the Asia-Pacific region, North America, South America, and Africa, rice is used as the main source of energy. The disadvantage of Thai rice is its high production cost and low yield per hectare, which affect the efficiency of its export in the ASEAN trade market. One major factor affecting the productivity of Thai rice is the bacterium Xanthomonas oryzae pv. oryzae (Xoo), which causes bacterial leaf blight (BLB). ${ }^{1-4}$ It occurs in both rainfed and irrigated fields in all regions of Thailand and has a high epidemic potential in many parts of the world, causing severe crop losses of up to $50-60 \%{ }^{5,6}$ Various disease control strategies have been used to reduce productivity losses and prevent rice disease spread. However, chemical-based strategies were unsuccessful because of differential sensitivity of the rice pathogenic species to the chemicals. In addition, the use of antibiotics and chemicals in the control of BLB is limited because of their toxic residues. ${ }^{7}$ Currently, BLB in rice is controlled by various chemicals, along with the use of diseaseresistant rice cultivars such as Suphan Buri 60, Suphan Buri 90, Suphan Buri 1, Suphan Buri 2 and Kor Khor 23. However, it is still not possible to control the disease effectively because of genetic variations in the pathogens, unstable resistant rice varieties, sensitivity of pathogen to different antibiotics or other environmental factors, and chemical resistant pathogens, which limit the potential of management strategies. The increasing desire to reduce pesticide use has led to the development of integrated pest management methods that make the best use of natural resources. Therefore, host plant-resistant varieties are the first important strategy for disease control.

Biological controls are on the list of alternative management strategies with high potential. Use of biological controls is a costeffective approach, which is less toxic to nontarget species and environment friendly. ${ }^{6,8-11}$ To reduce the loss of productivity due to disease, it is necessary to use environmentally friendly methods. Trichoderma spp. is a powerful antagonistic fungus that controls a wide range of plant diseases; it not only acts as a biological regulator, but also stimulates plant defense mechanisms against pathogens and promotes plant growth, resulting in higher crop yields. Biological control mechanisms include mycoparasitism, antibiosis, competition, and stimulation of plant defense mechanisms against pathogens. ${ }^{12}$ Several studies ${ }^{13-15}$ have reported the efficacy of Trichoderma in controlling Xoo, the causal agent of BLB in rice, in vitro, under greenhouse conditions, and in the field. For example, a comparison of the antagonism of Trichoderma against Xoo showed that $T$. harzianum showed the fastest growth with $62.3 \%$ mycelial growth after $72 \mathrm{~h}$ of incubation. Several species of Trichoderma completely inhibit the growth of Xoo. ${ }^{13}$ Volatile compounds produced by $T$. harzianum resulted in the lowest average Xoo growth radius, followed by T. hamatum. Non-volatile compounds of $T$. harzianum at a concentration of $6.25 \%$ inhibited Xoo growth by $51.1 \%$. Results showed that $T$. harzianum was the most effective isolate for reducing disease severity, with $48.26 \%$ and $59.22 \%$ reduction in disease severity, respectively. T. harzianum isolated from the phylloplane of rice can reduce disease severity and lead to higher yields compared to isolates from other sources. ${ }^{15}$

The most commonly used biological control agents are Bacillus spp.; they control pathogens by mechanisms, including antibiosis, competition, parasitism, and induction of systemic resistance, with antibiosis being the most important mechanism. ${ }^{16}$ El-Shakh et al. ${ }^{17}$ investigated the efficacy of endophytic bacteria in controlling the causal agent of BLB in rice (Xoo). Endophytic bacteria and rhizospheric Bacillus were tested for their antagonistic activity against Xoo in BLB. In vitro, all tested bacteria were found to have a high potential for antagonism against Xoo. Based on the results of 16S rRNA gene sequencing, Bacillus isolates can be classified as follows: Bacillus amyloliquefaciens, Bacillus methylotrophicus, and Bacillus subtilis. B. amyloliquefaciens FZB42 and B. amyloliquefaciens FZB42 produce the antimicrobial compounds difficidin and bacilysin, which inhibit Xanthomonas strains. Chen et al. ${ }^{18}$ demonstrated the ability of $B$. amyloliquefaciens 
FZB42 to target pathogenic microorganisms in rice, using the antibiotics difficidin and bacilysin. Interestingly, B. amyloliquefaciens FZB42 promoted plant growth and inhibited plant pathogens. The genome of FZB42 has been sequenced, and it contains a large gene cluster that produces several secondary metabolites with antimicrobial activity. The antibacterial activity is mainly due to the non-ribosomal synthesis of polyketides. ${ }^{19}$ Bacillus D13 also has antagonistic activity against Xoo. The volatile compounds of strain D13 decreased the colony size and motility of Xoo cultured on each plate. ${ }^{20}$

Serratia spp. belong to the Enterobacteriaceae family. Serratia is a gramnegative bacterium that is rod-shaped, and some species produce red pigments. Some strains of Serratia are harmful to pests, when consumed in large amounts. However, sometimes these species can be virulent even when insects are exposed to small amounts. They can kill insect larvae within 48-72 h, with larvae showing symptoms similar to those of a viral infection. ${ }^{21}$ In particular, red pigment-producing species have a greater effect on insects than nonpigmented species. ${ }^{22}$ Serratia sp. EML-SE1 has insecticidal potential that can kill diamondback moths. ${ }^{23}$ Control of several insect genera, such as Anomala, Costelytra, and Phyllophaga, can be achieved by entomopathogenic strains of Serratia entomophila. ${ }^{24}$ It was also found that control of grass moths (Costelytra zealandica) was possible with $S$. entomophila and $S$. proteamaculans. ${ }^{24-26}$ This confirms that these two species have insecticidal properties. ${ }^{27}$ Long-term pest management guidelines are required for the importation of exotic microorganisms and their subsequent release to destroy pests. Some insect pathogens are also used in this classical microbial management approach, which is related to antibiotic and siderophore production that can inhibit plant pathogens. The objective of this study was to compare the efficacy of secondary metabolites of the entomopathogenic bacterium S. nematodiphila GCSR38 with that of antagonistic microorganisms in controlling $\mathrm{XoO}$, the causal agent of BLB in rice, to provide a guide for future management strategies.

\section{MATERIALS AND METHODS Microorganisms}

The causative agent of $B L B$ in rice Xoo was obtained from the Plant Protection Research and Development Office of the Ministry of Agriculture and Cooperatives, Thailand. Antagonistic microorganisms, including nine antagonistic bacterial isolates (Bacillus sp.), five antagonistic fungal isolates (Trichoderma sp.), and one entomopathogenic bacterial isolate (Serratia nematodiphila GCSR38) were donated by the Microbiology Laboratory, Department of Biology, Faculty of Science, Mahasarakham University. All isolates were stored in $20 \%$ glycerol at $-20^{\circ} \mathrm{C}$ until use.

To confirm the species of GCSR38, the classification was repeated as follows: GCSR38 was grown on nutrient agar (NA) plates for $24 \mathrm{~h}$ at $37^{\circ} \mathrm{C}$, and colony morphology was observed, such as form, margin, and elevation. They were then Gram stained for microscopic observation. The $16 \mathrm{~S}$ rRNA gene was classified by sequencing. Genomic DNA of the GCSR38 strain was extracted using the CTAB method. ${ }^{28}$ Universal bacteria primers $27 \mathrm{~F}$ 5'-AGAGTTTGATC MTGGCTC AG-3' and 1492R 5'-TACGGYTAC CTTGTTACGACT T-3' were used for $16 \mathrm{~S}$ rRNA gene amplification. Amplifications were performed in a Gradient DNA Thermal Cycler programmed for the following parameter: $94^{\circ} \mathrm{C}$ for $5 \mathrm{~min}$, followed by 30 cycles of $94^{\circ} \mathrm{C}$ for $30 \mathrm{~s}, 52^{\circ} \mathrm{C}$ for $30 \mathrm{~s}, 72^{\circ} \mathrm{C}$ for $45 \mathrm{~s}$, and a final incubation at $72^{\circ} \mathrm{C}$ for $5 \mathrm{~min}$. PCR products were commercially sequenced by Macrogen Inc. (Seoul, South Korea). The 16S rRNA gene sequences of bacterium present in the NCBI database were used for alignment and comparison. Sequence data were obtained using BLAST for phylogenetic tree generation of the GCSR38 strain. Closely related sequences were downloaded and aligned using CLUSTAL X. ${ }^{29}$ Maximum parsimony (MP), maximum likelihood (ML), and neighbor-joining (NJ) methods were used for sequence analysis. ${ }^{30}$

\section{Efficacy of culture filtrates of effective microorganisms in controlling $\mathrm{XOO}$}

The agar well diffusion method was used to test the activity of the culture filtrate. First, antagonistic fungal culture filtrate was prepared by transferring three mycelia discs ( $8 \mathrm{~mm}$ diameter) of 
each isolate into $100 \mathrm{ml}$ of potato dextrose broth (PDB), which was then incubated at $28 \pm 2^{\circ} \mathrm{C}$ under static conditions for $7 \mathrm{~d}$. The culture filtrate was collected by separating the fungal mycelia through whatman no. 1 filter paper. The supernatant was centrifuged at $8,000 \times \mathrm{g}$ for $15 \mathrm{~min}$ to remove suspended particles, and filtered through a 0.22 um sterile membrane filter. Bacterial cultures maintained on NGA slants were aseptically inoculated into $10 \mathrm{ml}$ of nutrient glucose broth (NGB) and then incubated in a shaking incubator at $150 \mathrm{rpm}$ and $28 \pm 2^{\circ} \mathrm{C}$ for $48-72 \mathrm{~h}$. Bacterial cultures were centrifuged at $10,000 \times \mathrm{g}$ for $15 \mathrm{~min}$, and the supernatant was collected and filtered through a $0.22 \mu \mathrm{m}$ sterile membrane filter. Xoo cell suspension $\left(10^{8}\right.$ colony forming unit (CFU)/ml) was swabbed on NA plats, and an 8-mm diameter hole was drilled with a sterile cork borer at four points in a cross pattern. Next, $20 \mu \mathrm{l}$ of culture filtrate was added to the well. The agar plates were then incubated at $28 \pm 2^{\circ} \mathrm{C}$, and after $24-48$ $\mathrm{h}$ a clear zone was observed and measured. There were five replicates for each isolate, and 100 ppm rifampicin ${ }^{31}$ was used as a control.

\section{Secondary metabolite extraction}

For preparing secondary metabolites, antagonistic bacteria were cultured in NGB medium $(500 \mathrm{ml})$ and incubated under shaking at $150 \mathrm{rpm}$ and $28 \pm 2^{\circ} \mathrm{C}$ for $48-72 \mathrm{~h}$. Antagonistic fungi were cultured in PDB medium $(500 \mathrm{ml})$ under static conditions for $7 \mathrm{~d}$. To remove the bacterial cell pellet or fungal mycelia and spores, the culture flask was centrifuged at $10,000 \times \mathrm{g}$ at $4^{\circ} \mathrm{C}$ for 15 $\mathrm{min}$. The supernatant $(350 \mathrm{ml}$ of supernatant was extracted with $350 \mathrm{ml}$ ethyl acetate at a 1:1 ratio) and $5 \mathrm{~g}$ of $\mathrm{NaCl}$ were added for the first extraction. This extraction step was repeated three times. The supernatant in the upper phase of the separatory funnel was collected and pooled, and the solvents were evaporated in a rotary evaporator at $40^{\circ} \mathrm{C}$.

The effect of the antagonistic microorganism secondary metabolite crude extract (AMSMCE) on inhibition of $\mathrm{XOO}$

To determine the antibacterial effect of AMSMCE against Xoo, the paper disc diffusion method was used. The extract was dissolved in $1 \%$ DMSO to a final concentration of $2,000 \mu \mathrm{g} /$ $\mathrm{ml}$. A sterile filter paper disc $(6 \mathrm{~mm})$ containing $10 \mu \mathrm{l}$ of extract was placed on the surface of NGA plates already inoculated with $\mathrm{XoO}$ and incubated at $28 \pm 2^{\circ} \mathrm{C}$ for $24-48 \mathrm{~h}$. The inhibitory effect was determined by measuring the inhibition zone on a millimeter scale.

Determination of minimum inhibitory concentration (MIC) and minimum bactericidal concentration (MBC)

Determination of MIC was done using the method by Clinical and Laboratory Standards Institute. ${ }^{32}$ First, serial two-fold dilutions (1.95$1,000 \mu \mathrm{g} / \mathrm{ml}$ ) of the AMSMCE were added to 96well microtiter plates and $100 \mu \mathrm{l}$ of $\mathrm{Xoo}\left(10^{8} \mathrm{CFU} /\right.$ $\mathrm{ml}$ ) was added to each well. Then, $100 \mu$ l of Mueller Hinton broth (MHB) was added to well 1 to serve as the negative control, and $100 \mu \mathrm{l}$ of $100 \mathrm{ppm}$ rifampicin was added to well 12 to act a positive control, and the plate was incubated at $28 \pm 2^{\circ} \mathrm{C}$ for $24 \mathrm{~h}$. The OD600 was then measured using a Asys UVM 340 Microplate Reader (Biochrom)

MBC was assessed by placing samples from wells with concentrations above the MIC and MIC values and below the MIC values on an NA Petri plate, and the plate was incubated at $28 \pm 2{ }^{\circ} \mathrm{C}$ for $24 \mathrm{~h}$. The MBC value was assessed when no colony growth was observed on the NA plates.

The efficacy of AMSMCE in controlling rice BLB Detached leaf technique

Healthy leaves of Jasmin Rice 105 were selected for the detached leaf method. Rice leaves were washed with tap water for $5 \mathrm{~min}$, sprayed with $70 \%$ ethanol, and air-dried. Wounds were inflicted on the leaves using a sterilized inoculation needle (5 wounds/point). A completely randomized block design experiment was planned, consisting of four treatments as follows: (i) $10 \mu \mathrm{l}$ of AMSMCE was added $24 \mathrm{~h}$ before the addition of $10 \mu \mathrm{l}$ of $X o o$ cell suspension $\left(10^{8} \mathrm{CFU} / \mathrm{ml}\right)$, (ii) 10 $\mu \mathrm{l}$ of $\mathrm{Xoo}$ cell suspension $\left(10^{8} \mathrm{CFU} / \mathrm{ml}\right)$ was added

Table 1. Disease severity scale for bacterial leaf blight disease. $^{32}$

\begin{tabular}{cc}
\hline Disease Index & Score Lesion area (\%) \\
\hline 0 & 0 \\
1 & $0-10$ \\
3 & $11-30$ \\
5 & $31-50$ \\
7 & $51-75$ \\
9 & $76-100$
\end{tabular}


Table 2. Efficacy of effective microorganism culture filtrate to control Xanthomonas oryzae pv. oryzae by agar well diffusion method

\begin{tabular}{lcc}
\hline Isolates & & Inhibition zone ${ }^{1 /}(\mathrm{mm})$ \\
\hline Antagonistic fungi & Trichoderma sp. SK24 & $19.75+0.71 \mathrm{bc}$ \\
& Trichoderma sp. UBO7 special & $20.75+0.98 \mathrm{bc}$ \\
& Trichoderma sp. UB04/3 & $20.01+1.55 \mathrm{bc}$ \\
& Trichoderma sp. UB05/3 & $22.97+1.58 \mathrm{ab}$ \\
& Trichoderma sp. WU01 & $20.13+0.33 \mathrm{bc}$ \\
Antagonistic bacteria & Bacillus sp. BWPD-KK23 & $12.32+0.39 \mathrm{bcd}$ \\
& Bacillus sp. BWTM-MSU2 & $17.90+1.87 \mathrm{bc}$ \\
& Bacillus sp. BWWM-MSU16 & $19.15+1.00 \mathrm{bc}$ \\
& Bacillus sp. BWTM-MSU6 & $8.49+0.43 \mathrm{~cd}$ \\
Bacillus sp. BWWM-MSU6 & $8.28+0.46 \mathrm{~cd}$ \\
Bacillus pumilus FDKF5 & $12.27+1.35 \mathrm{bcd}$ \\
Bacillus sp. GCMR18 & $12.52+1.00 \mathrm{bcd}$ \\
Bacillus sp. GCMR44 & $9.07+0.79 \mathrm{~cd}$ \\
Bacillus sp. IKM1 & $10.59+0.33 \mathrm{bcd}$ \\
Negative control & dHo & $18.25+1.25 \mathrm{bc}$ \\
& Rifampicin & $0.00+0.00 \mathrm{~d}$ \\
& CV (\%) & $32.87+1.89 \mathrm{a}$ \\
& Serratia nematodiphila GCSR38 & 6.61 \\
\hline
\end{tabular}

${ }^{1 /}$ Different superscripts within the same column indicate a significant difference $(P<0.05)$.

$24 \mathrm{~h}$ before the addition $10 \mu \mathrm{l}$ of AMSMCE, (iii) 10 $\mu \mathrm{L}$ of $\mathrm{Xoo}$ cell suspension $\left(10^{8} \mathrm{CFU} / \mathrm{ml}\right)$ was added, and (iv) $10 \mu \mathrm{L} \mathrm{dH}_{2} \mathrm{O}$ was added. All plants were incubated in a moist chamber for $7 \mathrm{~d}$. For disease rating, a modified scale was used..$^{33}$ (Table 1 ).

Disease severity was calculated with the followed formula:

$$
\mathrm{SI}=[\Sigma(\mathrm{Ni} \times \mathrm{Vi}) /(\mathrm{V} \times \mathrm{N})] \times 100
$$

$\mathrm{Ni}=$ number of leaves in each disease
$\mathrm{Vi}=$ disease scale in each leaf

$\mathrm{V}=$ maximum disease scale

$\mathrm{N}=$ number of leaves

\section{Pot experiments}

Jasmin rice 105 was used as the test crop. The experiments in the pots were designed as a completely randomized experiment with four replicates, using three 21 -d-old seedlings in each pot. The clipping method with sterilized scissors scale

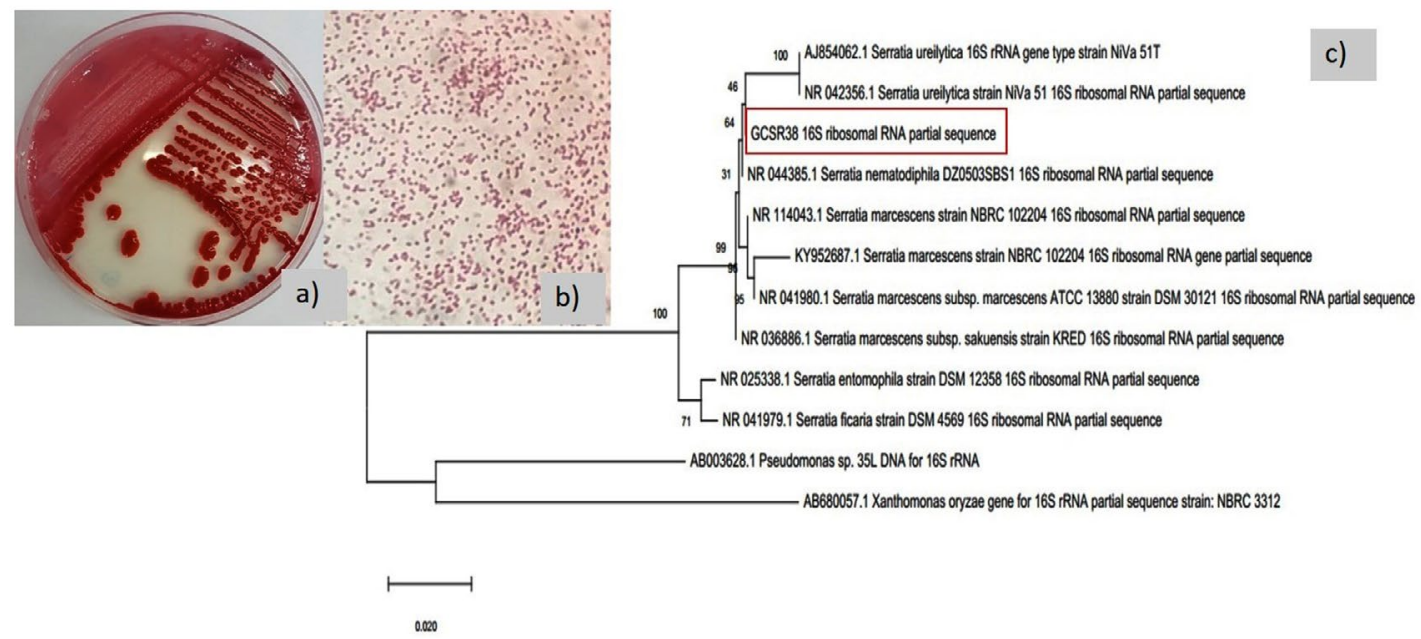

Fig. 1. Characteristic of GCSR3 a) colony morphology b) gram stain c) phylogenetic tree base on $16 \mathrm{~S}$ rRNA sequence. 
Table 3. Effect of antagonistic microorganism secondary metabolites crude extracts (AMSMCE) against Xanthomonas oryzae pv. oryzae by using agar well diffusion technique

\begin{tabular}{lcc}
\hline Isolates & & Inhibition zone $^{1 /}(\mathrm{mm})$ \\
\hline Antagonistic fungi & Trichoderma sp. SK24 & $0.00+0.00 \mathrm{c}$ \\
& Trichoderma sp. UB07 special & $0.00+0.00 \mathrm{c}$ \\
& Trichoderma sp. UB04/3 & $0.00+0.00 \mathrm{c}$ \\
& Trichoderma sp. UB05/3 & $0.00+0.00 \mathrm{c}$ \\
Trichoderma sp. WU01 & $0.00+0.00 \mathrm{c}$ \\
& Bacillus sp. BWTM-MSU2 & $0.00+0.00 \mathrm{c}$ \\
Negative control & Bacillus sp. BWWM-MSU16 & $0.00+0.00 \mathrm{c}$ \\
Positive control & Serratia nematodiphila GCSR38 & $17.60+1.06 \mathrm{~b}$ \\
& dH O & $0.00+0.00 \mathrm{c}$ \\
& Rifampicin & $32.70+0.52 \mathrm{a}$ \\
& $\mathrm{CV}(\%)$ & 8.97 \\
\hline
\end{tabular}

1/ Different superscripts within the same column indicate a significant difference $(P<0.05)$.

Table 4. Effect of S. nematodiphila GCSR38 secondary metabolites crude extract to control rice bacterial leaf blight disease by using detached leaf technique, 7 days after inoculations

\begin{tabular}{lc}
\hline Treatment & Disease Severity $(\%)^{1 /}$ \\
\hline 1. Inoculate GCSR38 extract 24 h before Xoo & $24.45+3.85 \mathrm{~b}$ \\
2. Inoculates Xoo 24 h before GCSR38 extract & $15.56+10.18 \mathrm{~b}$ \\
3. X. oryzae pv. oryzae (Xoo) & $44.45+3.85 \mathrm{a}$ \\
4. $\mathrm{dH}_{2} \mathrm{O}$ & $0.00+0.00 \mathrm{c}$ \\
$\mathrm{CV}(\%)$ & 27.35 \\
\hline
\end{tabular}

${ }^{1 /}$ Different superscripts within the same column indicate a significant difference $(P<0.05)$.

was used along with Xoo spraying. ${ }^{34}$ The four treatments were as follows: (i) Xoo treatment $24 \mathrm{~h}$ before spraying with AMSMCE, (ii) Xoo treatment only, as a negative control, (iii) zinc thiazole treatment as a positive control, and (iv) $\mathrm{dH}_{2} \mathrm{O}$ treatment. The inoculated plants were incubated in a humid chamber for $7 \mathrm{~d}$. Disease severity was scored according to the formula above.

\section{RESULTS}

Identification of Serratia nematodiphila GCSR38

The morphology of $S$. nematodiphila GCSR38 colony on NA plates was as follows: red and circular, with entire margins, umbonate elevation, smooth, gram-negative, short rod, and not endospore-forming. The $16 \mathrm{~S}$ rRNA sequence showed that GCSR38 had $99.93 \%$ similarity with Serratia nematodiphila DZ0503SBS1 (Fig. 1).
The efficacy of the effective microorganism culture filtrate in controlling Xoo

The efficiency of antagonistic bacteria and antagonistic fungi culture filtrate against $X o o$ was tested using the agar well method. Trichoderma sp. UB05/3 showed the best inhibition of pathogen growth and was not statistically different from 100 ppm rifampicin with inhibition zone diameters equal to $22.97+1.58 \mathrm{~mm}$ and $32.87+1.89$ $\mathrm{mm}$, respectively (Table 2 ). All isolates of the antagonistic microbial culture filters showed $X_{0 O}$ inhibition compared to the inhibition observed in case of $\mathrm{dH} 2 \mathrm{O}$. The inhibition by other seven isolates was not statistically different from that of Trichoderma sp. UB05/3, Trichoderma sp. SK24, UB07 special, UB04/3, WU01, Bacillus sp. The efficacy of BWTM-MSU2, BWWM-MSU16, and $S$. nematodiphila GCSR38 was tested in the next step. 


\section{The effect of AMSMCE on the inhibition of Xoo}

AMSMCE was tested for Xoo inhibition using the paper disc diffusion method. The results showed that only the crude extract of secondary metabolites from S. nematodiphila GCSR38 could inhibit the growth of Xoo with a $17.60+1.06$ $\mathrm{mm}$ inhibition zone, while rifampicin (positive control) showed a $32.70+0.52 \mathrm{~mm}$ inhibition zone (Table 3).

\section{Determination of MIC and MBC}

The MIC of S. nematodiphila GCSR38 secondary metabolite crude extract against Xoo was $1,000 \mu \mathrm{g} / \mathrm{ml}$. The MBC screening indicated that $S$. nematodiphila GCSR38 secondary metabolite crude extracts tested against $X o O$ at $1,000 \mathrm{ug} / \mathrm{ml}$ showed no colony-forming ability, indicating that the $\mathrm{MBC}$ value for this extract was $1,000 \mu \mathrm{g} / \mathrm{ml}$ (Fig. 2).

Table 5. Effect of S. nematodiphila GCSR38 secondary metabolites crude extract to control rice bacterial leaf blight disease in potted rice plants under greenhouse conditions, 7 days after inoculations

\begin{tabular}{lc}
\hline Treatment & Disease Severity (\%) ${ }^{1 /}$ \\
\hline 1. Inoculates Xoo 24 h & $28.89+3.85 \mathrm{~b}$ \\
before GCSR38 extract & \\
2. X. oryzae pv. oryzae & $66.67+0.00 \mathrm{a}$ \\
3. Zinc thiazol & $22.22+3.85 \mathrm{c}$ \\
4. $\mathrm{dH}_{2} \mathrm{O}$ & $0.00+0.00 \mathrm{~d}$ \\
$\mathrm{CV}(\%)$ & 9.24 \\
\hline
\end{tabular}

$1 /$ Different superscripts within the same column indicate a significant difference $(\mathrm{P}<0.05)$.
The efficacy of GCSR38 secondary metabolite crude extracts against Xoo

Detached leaf technique

Seven days after inoculation, the results showed that $S$. nematodiphila GCSR38 secondary metabolite crude extracts could reduce disease severity with a severity index less than that of the only Xoo treatment. Using the extracts $24 \mathrm{~h}$ before and after inoculation with $X o o$, we found that the disease severity index was not significantly different and was $24.45 \%$ and $15.56 \%$, respectively (Table 4).

\section{Pot experiments}

Inoculation of Xoo $24 \mathrm{~h}$ before spraying S. nematodiphila GCSR38 secondary metabolite crude extracts reduced the incidence of rice BLB by $28.89 \%$; spraying with zinc thiazol yielded significantly different results compared to those by other treatments, with $22.22 \%$ disease severity (Table 5).

\section{DISCUSSION}

Morphological and molecular characterization of strain GCSR38 indicated that it was S. nematodiphila. This result is similar to that by Zhang et al., ${ }^{35}$ who reported the isolation of the bacterium Serratia DZ0503SBS1(T) from the intestine of a nematode (Heterorhabditidoides chongmingensis); it produced red pigment, was gram-negative, mobile, fluorescent, odd-shaped, and had a unilateral flagellum. A comparative analysis of $16 \mathrm{~S}$ rRNA gene sequences showed that DZ0503SBS1(T) is a novel species named S. nematodiphila sp. nov. The culture filtrates

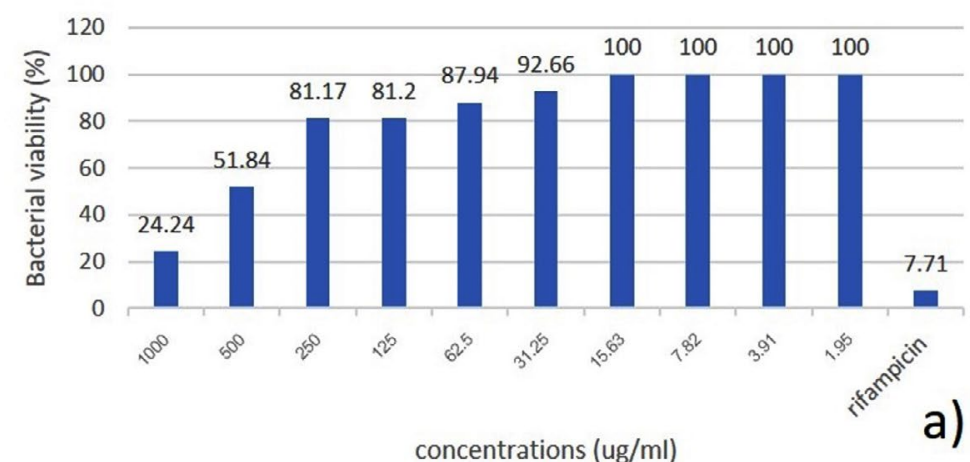

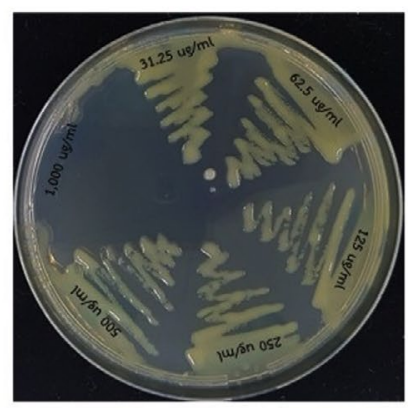

a)

b)

Fig. 2. Minimum inhibitory concentration (MIC) and minimum bactericidal concentration (MBC) of secondary metabolites crude extracts against $X$. oryzae pv. oryzae a) MIC b) MBC. 
of all fungal isolates (Trichoderma spp.) could inhibit the rice BLB pathogen, while the culture filtrates of all antagonistic bacterial isolates could inhibit the pathogens, but their efficacy was lesser than that of the antagonistic fungi. When extracting secondary metabolites with ethyl acetate, only the entomopathogenic bacterium S. nematodiphila GCSR38 was found to inhibit Xoo in vitro. Gangwar and Sinha ${ }^{14}$ screened Trichoderma spp. and studied their biocontrol abilities against $X o o$ isolates obtained from ricegrowing areas of various states. Trichoderma spp. isolated from Pantnagar were able to inhibit the growth of $\mathrm{XOO}$ isolated from Pantnagar and from other locations by $100 \%$. Trichoderma spp. can inhibit the radial growth of Xoo with 89.8 $\%$ inhibition for both isolates from Kashipur; however, $100 \%$ inhibition was obtained using Trichoderma spp. isolated from Pantnagar and Haldwani. GC-MS was used for further analysis of antibacterial activity against the rice BLB pathogen. The results revealed that the dual culture of Trichoderma spp. showed a larger inhibition zone than the monoculture. This indicates that better stimulation of novel secondary metabolites can be achieved by dual culture of beneficial fungi and is better than monoculture. ${ }^{36}$ Prabawati et al. ${ }^{37}$ performed isolation, selection, and identification of phyllosphere bacteria against Xoo. The plug agar method was used to screen the antagonistic activity of 52 isolates of phyllosphere bacteria. The results showed that the seven isolates could inhibit Xoo. The morphology and molecular characteristics of these antagonistic bacteria were used to classify them in the genera Bacillus and Arthrobacter. Nagendran et al. ${ }^{38}$ managed BLB using endophytic bacteria. The results of the in vitro study showed a significantly higher inhibition of Xoo, including five isolates of $B$. subtilis var. amyloliquefaciens. Halim et al. ${ }^{39}$ screened and characterized bacterial isolates that had potential antagonistic activity against Xoo. Only 17 endophytic bacterial isolates showed positive antagonistic activity, which was indicated by inhibition zones against $X O O$ around bacterial colonies on NA plates. While isolating and identifying soil bacteria antagonistic to $X o o$, it was found that among 830 isolates, CT-66, CT-78, and CT-88 strains exhibited strong antagonistic effects against the pathogen. These effects are associated with antibiotics. Based on the 16S rRNA gene sequence, morphology, and biochemical properties, strain CT-78 was identified as $S$. nematodiphila. ${ }^{40}$ The biochemical synthesis of bacterial secondary metabolites involves multiple enzymatic pathways and structural heterogeneous reactions that give rise to their highly specific mechanisms of action. The genus Serratia lives in a wide variety of environments and has a large amount of plaque, which is considered a source of exotic and biologically important structural secondary metabolites with potential activities include antioxidants, antimicrobial and immunesuppressive properties. ${ }^{41} \mathrm{~S}$. nematodiphila RL2 produces a red pigment called prodigiosin. Prodigiosin is an antimicrobial agent that is effective in controlling Listeria spp., Pseudomonas spp., Yersinia spp., and Shigella spp. ${ }^{42}$

The MIC of GCSR38 secondary metabolite extracts against $X o 0$ was $1,000 \mu \mathrm{g} / \mathrm{ml}$, and the $\mathrm{MBC}$ value for this exact was also $1,000 \mu \mathrm{g} / \mathrm{ml}$. S. nematodiphila GCSR38 secondary metabolite extracts can reduce the disease severity of BLB in vitro and in vivo. This is similar to the findings of Shi et al., ${ }^{43}$ who reported the role of Streptomyces roseoverticillatus 63 (Sr-63) against Xoo; disease suppression was accomplished under glasshouse conditions. In addition, carbazomycin B isolated from the fermented broth of strain $\mathrm{Sr}-63$ was found to be active against $X_{o o}$, with an MIC of $8 \mu \mathrm{g} / \mathrm{ml}$. Bioactivity analysis showed that the compounds isolated from Pseudomonas aeruginosa (LN strain) inhibited three Xanthomonas strains under greenhouse conditions. In vivo testing under greenhouse conditions for fractions with antibiotic activity and their bioactivity evaluation is essential. Spraying plants with semi-purified fractions can control Xanthomonas spp. ${ }^{44}$

\section{ACKNOWLEDGMENTS}

The author is thankful to Mahasarakham University for financial support and towards research equipment. The author is also grateful to Dr. Adrian Roderick Plant for English language editing.

\section{FUNDING}

This research project was financially supported by Mahasarakham University, Thailand (Grant No. 6308038). 


\section{DATA AVAILABILITY}

All datasets generated or analyzed during this study are included in the manuscript.

\section{ETHICS STATEMENT}

This article does not contain any studies with human participants or animals performed by the author.

\section{REFERENCES}

1. Saha S, Garg R, Biswas A, Rai AB. Bacterial Diseases of Rice: An Overview. J Pure Appl Microbiol. 2015;9(1): 725-736.

2. Hastuti RD, Lestari $Y$, Suwanto A, Saraswati R. Endophytic Streptomyces spp. as biocontrol agents of rice bacterial leaf blight pathogen (Xanthomonas oryzae pv. oryzae). HAYATI J Biosci. 2012;19(4): 155162. doi: 10.4308/hjb.19.4.155

3. Li B, Liu B, Shan C, et al. Antibacterial activity of two chitosan solutions and their effect on rice bacterial leaf blight and leaf streak. Pest Manag Sci. 2013;69: 312-320. doi: 10.1002/ps.3399

4. Wu L, Wu H, Chen L, Yu X, Borriss R, Gao X. Difcidin and bacilysin from Bacillus amyloliquefaciens FZB42 have antibacterial activity against Xanthomonas oryzae rice pathogens. Sci Rep. 2015;5:1-9. doi: 10.1038/ srep12975.

5. Gnanamanickam SS, Priyadarisini VB, Narayanan NN, Vasudevan P, Kavitha S. An overview of bacterial blight disease of rice and strategies for its management. Current Sci. 1999;77(11):1435- 1443.

6. Yasmin S, Zaka A, Imran A, et al. Plant growth promotion and suppression of bacterial leaf blight in rice by inoculated bacteria. PLOS One. 2016;11(8):1-19. doi: 10.1371/journal.pone.0160688

7. MacManus PS, Stockwell VO, Sundin GW, Jones AL. Antibiotic use in plant agriculture. Ann Rev Phytopathol. 2002;40: 443-465. doi: 10.1146/annurev. phyto. 40.120301 .093927

8. Nelson LM. Plant growth promoting rhizobacteria (PGPR): Prospects for new inoculants. Online. Crop Management. 2004. doi:10.1094/CM-2004-0301-05RV.

9. Chithrashree, Udayashankar AC, Nayaka SC, Reddy MS, Srinivas C. Plant growth promoting rhizobacteria mediate induced systemic resistance in rice against bacterial leaf blight caused by Xanthomonas oryzae pv. oryzae. Biol Control. 2011;59: 114-122. doi: 10.1016/j. bio control.2011.06.010

10. Bhattacharyya PN, Goswami MP, Bhattacharyya LH. Perspective of beneficial microbes in agriculture under changing climatic scenario: J Phytol. 2016;8: 26-41. doi: 10.19071/jp. 2016.v8.3022

11. Liu K, Garret C, Fadamiro H, Kloepper JW. Antagonism of black rot in cabbage by mixture of plant growthpromoting rhizobacteria (PGPR). Bio Control. 2016; 61: 605-613. doi: 10.1007/s10526-016-9742-3

12. Naher L, Yusuf U, Ismail A, Hossain K. Trichoderma spp.: A biocontrol agent for sustainable management of plant diseases. Pak J Bot. 2014;46(4): 1489-1493.
13. Gangwar GP, Sinha AP. Comparative antagonistic potential of Trichoderma spp. against Xanthomonas oryzae pv. oryzae. Ann Pl Protec Sci. 2010; 18(2): 458-463. https://www.researchgate.net/ publication/221655149_Comparative_antagonistic_ potential_of_Trichoderma_spp_against_ Xanthomonas_oryzae_pv_oryzae

14. Gangwar GP, Sinha AP. Comparative antagonistic potential of fungal and bacterial bioagents against isolates of Xanthomonas oryzae pv. oryzae. Ann PIProtec Sci. 2012;20(1): 154-159. https://www.indianjournals. com/ijor.aspx?target=ijor:apps\&volume $=20 \&$ issue $=1 \&$ article $=035$

15. Gangwar GP. Field efficacy of formulation of fungal bioagents against bacterial leaf blight of rice caused by Xanthomonas oryzae pv. oryzae (Uyeda and Ishiyama) Dowson. J Appl Nat Sci. 2013;5(2):423-426.

16. Thomashow LS, Weller DM. Current concepts in the use of introduced bacteria for biological disease control: mechanisms and antifungal metabolites. In: Stacey G, Keen NT (Eds.). Plant-Microbe Interactions. New York: Chapman and Hall 1, 1996, 87-235.

17. El-shakh ASA, Kakar KU, Wang $X$, et al. Controlling bacterial leaf blight of rice and enhancing the plant growth with endophytic and rhizobacterial Bacillus strains. Toxicol Envi Chem. 2015;97(6):766-785. doi:1 0.1080/02772248.2015.1066176

18. Chen $\mathrm{XH}$, Koumoutsi A, Scholz R, et al. Genome analysis of Bacillus amyloliquefaciens FZB42 reveals its potential for biocontrol of plant pathogens. J Biotechnol. 2009;140: 27-37. doi: 10.1016/j. jbiotec.2008.10. 011

19. Chen $\mathrm{XH}$, Vater J, Piel J, et al. Structural and functional characterization of three polyketide synthase gene clusters in Bacillus amyloliquefaciens FZB 42. J Bacterio. 2006;188: 4024-4036. doi: 10.1128/ JB.00052-06

20. Cock LS, Guarnizo AFC, Guerrero CAR. Antimicrobial activity and fermentation kinetics of Weissella confusa against Xanthomonas albilineans. Acta Agron. 2013; 52(2):97-104.

21. Lysyk TJ, Kalischuk-Tymensen LD, Selinger LB. Comparison of selected growth media for culturing Serratia marcescens, Aeromonas sp., and Pseudomonas aeruginosa as pathogens of adult Stomoxys calcitrans (Diptera: Muscidae). J Med Entomol. 2002;39: 89-98. doi: 10.1603/0022-2585-39.1.89

22. Grimont PAD, Grimont F, Dulongderosnay HLC, Sneath PHA. Taxonomy of the genus Serratia. J Gen Microbiol. 1977;98:39-66. doi: 10.1099/00221287-98-1-39.

23. Jeong $\mathrm{HU}, \mathrm{Mun} \mathrm{HY}, \mathrm{Oh} \mathrm{HK}$, et al. Evaluation of insecticidal activity of a bacterial strain, Serratia sp. EML-SE1 against diamondback moth. J Microbiol. 2010; 48(4): 541-545. doi: 10.1007/s12275-010-02219

24. Nunez-Valdez ME, Calderon MA, Aranda E, et al. Identification of a putative Mexican strain of Serratia entomophila pathogenic against root-damaging larvae of Scarabaeidae (Coleoptera). Appl Environ Microbiol, 2008;74: 802-810. doi: 10.1128/AEM. 01074-07

25. Jackson TA, Boucias DG, Thaler JO. Pathobiology of amber disease, caused by Serratia spp., in the 
New Zealand grass grub, Costelytra zealandica. J Invertebr Pathol, 2001;78(4): 232-243. doi: 10.1006/ jipa.2002.5078

26. Sikorowski PP, Lawrence AM, Inglis GD. Effects of Serratia marcescens on rearing of the tobacco budworm (Lepidoptera: Noctuidae). Am Entomol, 2001;47: 51-60. doi:10.1093/ ae/47.1.51

27. Patil CD, Patil SV, Salunke BK, Salunkhe RB. Insecticidal potency of bacterial species Bacillus thuringiensis SV2 and Serratia nematodiphila SV6 against larvae of mosquito species Aedes aegypti, Anopheles stephensi, and Culex quinquefasciatus. Parasitol Res, 2012;110: 1841-1847. doi: 10.1007/s00436-011-2708-6

28. Ausubel FM, Brent R, Kingdton RE, et al. Current protocols in molecular biology. New York: Greene Publishing Association; Wiley-Interscience, 1992. v.1.

29. Thompson JD, Gibson TJ, Plewniak F, Jeanmougin F, Higgins DG. The CLUSTAL_X windows interface: flexible strategies for multiple sequence alignment aided by quality analysis tools. Nucleic Acids Res. 1997;25: 4876-4882. doi: 10.1093/nar/25.24.4876

30. Mirza BS, Welsh A, Rasul G, Rieder JP, Paschke MW, Hahn D. Variation in Frankia populations of the Elaeagnus host infection group in nodules of six host plant species after inoculation with soil. Microb Eco. 2009;58: 384-393. doi: 10.1007/s00248-009-9513-0

31. Cheng CM, Tu J, Yang CC, Kuo TT. Rifampicin: an inhibitor of Xp12- specific protein phosphorylation. FEMS Microb Lettes. 1996;143: 141-149.

32. Clinical and Laboratory Standards Institute. Method for dilution antimicrobial susceptibility teste for bacterial that grow aerobically. $11^{\text {th }}$ Edition. Clinical and Laboratory Standards M07. 2018. https://clsi.org/ media/1928/m07ed11_sample.pdf

33. Chaudhary RC. Fukuyi. Internationalization of elite germplasm for farmers: Collaborative mechanisms to enhance evaluation of rice genetic resources. In: New Approaches for Improved use of Plant Genetic Resources, Japan.1996:26. https://www.researchgate. net/publication/318494793

34. Kauffman HE, Reddy APK, Hsieh SPY Merca SD. An improved technique for evaluating resistance of rice varieties to Xanthomonas oryzae. Plant Dis Rep. 1973; 57: 537-541.

35. Zhang CX, Yang SY, Xu MX, et al. Serratia nematodiphila sp. nov., associated symbiotically with the entomopathogenic nematode Heterorhabditidoides chongmingensis (Rhabditida: Rhabditidae). Int J Syst Evol Microbiol, 2009;59(7):1603-1608. doi: 10.1099/ ijs.0.65718-0

36. Shobha B, Lakshmeesha TR, Ansari MA, et al. Mycosynthesis of ZnO nanoparticles using Trichoderma spp. isolated from rhizosphere soils and its synergistic antibacterial effect against Xanthomonas oryzae pv. oryzae. J fungi. 2020;6(3): 181. doi: 10.3390/ jof6030181

37. Prabawati A, Susilowati A, Sugiyato S. Phyllosphere bacteria as a candidate of biocontrol agents against Xanthomonas oryzae pv. oryzae (Xoo) causes bacterial blight disease. Pros Sem Nas Masy Biodiv Indon. 2019; 5(2): 256-262. doi:10.13057/psnmbi/m050219

38. Nagendra K, Karthikeyan G, Raveendran M, Prabakar $\mathrm{K}$, Raguchander T. Management of bacterial leaf blight disease in rice with endophytic bacteria. World Appl Sci J. 2014;28(12):2229-2241. doi: 10.5829/idosi. wasj.2013.28.12.2009

39. Halim RA, Hasan NA, Ramachandran K. Screening of endophytic bacteria as biocontrol agents against bacteria leaf blight (Xanthomonas oryzae). HAYATI J Biosci. 2020;27(3): 215-220. doi: 10.4308/hjb.27.3.215

40. Khoa ND, Giàu NDN, Tuấn TQ. Effects of Serratia nematodiphila CT-78 on rice bacterial leaf blight caused by Xanthomonas oryzae pv. oryzae. Bio Control. 2016; 103: 1-10. doi: 10.1016/j.biocontrol.2016.07.010

41. Al-Ghanem MM. Serratia a novel source of secondary metabolites. Adv Biotech \& Micro. 2018;11(3):1-5. doi: 10.19080/AIBM.2018.11.555814.

42. Gondil VS, Asif M, Bhalla TC. Optimization of physicochemical parameters influencing the production of prodigiosin from Serratia nematodiphila RL2 and exploring its antibacterial activity. 3 Biotech. 2017;7: 338. doi: 10.1007/s13205-017-0979-z

43. Shi T, Guo X, Zhu J, Hul J, He Z, Jiang D. Inhibitory effects of carbazomycin B produced by Streptomyces roseoverticillatus 63 against Xanthomonas oryzae pv. oryzae. Front Microbiol. 2021;12(6):1-13. doi: 10.3389/ fmicb.2021.616937

44. Spago FR, Mauro CSI, Oliveira AG, et al. Pseudomonas aeruginosa produces secondary metabolites that have biological activity against plant pathogenic Xanthomonas species. Crop Protec. 2014;62:46-54. doi: 10.1016/ j.cropro.2014.04.011 